\title{
Flavonoid Composition of Three Genotypes of Dry Bean (Phaseolus vulgaris) Differing in Seedcoat Color
}

\author{
Clifford W. Beninger ${ }^{1}$ and George L. Hosfield ${ }^{2}$ \\ U.S. Department of Agriculture, Agricultural Research Service, Sugarbeet and Bean Research, Department \\ of Crop and Soil Sciences, Michigan State University, East Lansing, MI 48824
}

\author{
Mark J. Bassett ${ }^{3}$ \\ Institute of Food and Agricultural Sciences, Horticultural Sciences Department, University of Florida, \\ Gainesville, FL 32611-0690
}

\begin{abstract}
AdDitional INDEX WORDs. kaempferol, flavonol glycoside, astragalin, tannins, genetics
Abstract. Three dry bean (Phaseolus vulgaris L.) genotypes differing in seedcoat color, mineral brown (PCDJGB v), yellow brown $(P C D J G b v)$, and pale greenish yellow $(P C D J g b v)$, were analyzed phytochemically. Kaempferol 3- $O$ - $\beta$-D-glucoside (astragalin) was isolated and identified by nuclear magnetic resonance spectroscopy from all three genotypes, and was the main flavonoid monomer present. Flavonoid polymers (condensed tannins) were detected by thin layer chromatography, but anthocyanins were not detected in the three genotypes. High pressure liquid chromatography analyses indicated that astragalin was present at similar concentrations in pale greenish yellow and mineral brown genotypes, but was significantly lower in yellow brown. Presently, we do not know the functions of the $G$ and $B$ color genes, although the presence of astragalin in the three genotypes studied indicates these genes do not appear to act in a qualitative manner with regard to astragalin production, but may control the amount of astragalin present. Subtle differences in color between these genotypes may be due to the amount and type of tannins which have secondarily polymerized with phenolics and flavonoid monomers.
\end{abstract}

Knowledge of the genetics and chemistry of seedcoat color and patterns in $P$. vulgaris (dry bean) is due mainly to the work of Kooiman (1931), Lamprecht (1932), and Feenstra (1960). In $P$. vulgaris, eight major loci are known to contribute to color inheritance: $P, C, D, J, G, B, V$ and $R k$ (Prakken, 1970, 1972). The complex $C$ locus also includes a dominant gene $R$ for red seedcoat color (Prakken, 1972). According to Prakken's (1972) interpretation of seedcoat color in common bean, $C, D$, and $J$ are the color genes, whereas $G, B, V$, and $R k$ are modifying genes (have an intensifying effect or darkening influence upon pale colors formed by the action of the color genes). $V$ is also called the violet factor and the dominant allele causes bluish, or violet to black, colors to develop in the seedcoat.

The work of Kooiman (1931) and Lamprecht (1932) demonstrated that the seedcoat colors of common bean are not affected by the genetic background, but only by the complex interactions of the eight major loci cited above. Thus, seedcoat colors are qualitatively inherited. Feenstra (1960) studied the pigment chemistry of 12 genotypes, each with a different combination of alleles at $C, J$, and $V$. One of the 12 genotypes was 'Canadian Wonder Improved.' The remaining 11 genotypes were derived by inbreeding to homozygosity from 8 different parental cross combinations, which involved 5 named varieties and eight numbered breeding lines. Thus, the genetic backgrounds of his 12 seedcoat genotypes were greatly more diverse than the genetic backgrounds of the three used in the present work. The great genetic

Received for publication 27 Oct. 1998. Accepted for publication 20 May 1999. Names are necessary to report factually on available data; however, the USDA neither guarantees nor warrants the standard of the product, and the use of the name by the USDA implies no approval of the product to the exclusion of others that may also be suitable. The cost of publishing this paper was defrayed in part by the payment of page charges. Under postal regulations, this paper therefore must be hereby marked advertisement solely to indicate this fact.

${ }^{1}$ Postdoctoral research associate.

${ }^{2}$ Research geneticist, to whom reprint requests should be addressed.

${ }^{3}$ Professor. diversity of the genetic backgrounds of the materials used by Feenstra (1960) had no effect on the results of the chemical analyses reported.

Feenstra (1960) studied the flavonoids produced by different alleles at the $C, J$ (same as his $S h$ ), and $V$ loci, but no work to fully elucidate all the flavonoids of various color genotypes has since been published. To date, our knowledge of the flavonoid gene products has been inferred from other plant systems (Leakey, 1988). Leakey (1988) proposed that dominance at the $C$ locus promotes the formation of flavonol glycosides and also allows formation of anthocyanins. Dominance at the $J$ locus is thought to be necessary for production of proanthocyanidins (condensed tannins) in the seedcoat (Feenstra, 1960). Other genes may be responsible for glycosylation of the flavonoid nucleus, as well as hydroxymethylation of the A and $\mathrm{B}$ rings.

The metabolic pathway for flavonoid biosynthesis begins with isomerization of chalcone to form a flavanone, which is then converted successively into the flavonols dihydrokaempferol and kaempferol (Heller and Forkmann, 1988). These pathways, and the genes that control them, have been elucidated for such plant species as maize (Zea mays L.) and petunia (Petunia hybrida Hort. Vilm.-Andr.) (Koes et al., 1993). However, the pathways and gene products of $P$. vulgaris have not been elucidated, and current models are speculative. We determined previously that 'Prim', a manteca-type market class bean with the genotype $P C$ $d j G b v^{\text {lae }}$ (Bassett, 1999), contained the flavonols kaempferol3-O-glucoside and kaempferol-3-O-glucosylxyloside in the seedcoat, but 'Prim' did not contain detectable levels of proanthocyanidins (Beninger et al., 1998a). Although our analysis of 'Prim' was of interest because of the recessive state at several loci, we were not able to determine the functions of the $G$ and $B$ genes.

Recently, a number of seedcoat color genotypes have been made available for research. Three of these color genotypes- $P$ $C D J G B v$ (mineral brown), $P C D J G b v$ (yellow brown) and 
$P C D J g b v$ (pale greenish-yellow) - differ by successive recessive substitutions at the $G$ and $B$ loci. The purpose of this paper was to identify and compare the specific kinds and concentrations of flavonoids found in these three seedcoat genotypes in order to determine the functions of the $G$ and $B$ seedcoat color genes.

\section{Materials and Methods}

Plant material. The three genetic stocks used for this investigation were developed by Bassett (1998a) by backcrossing selected recessive genes for seedcoat color into a recurrent parent breeding line 5-593. Line 5-593 has dominant genes for seedcoat color in all eight color loci $(P[C r] D J G B V R k)$, except for the dominant red locus $R$, which is tightly linked to the $C$ locus (Bassett, 1998b; Prakken, 1970). The three genetic stocks are in the third backcross to the recurrent parent 5-593 and are designated $v \mathrm{BC}_{3} 5-593$ (mineral brown), $b v \mathrm{BC}_{3}$ 5-593 (yellow brown) and $g b v \mathrm{BC}_{3} 5-593$ (pale greenish-yellow) (Bassett, 1998a). The three genetic stocks are not isogenic with respect to the recurrent parent 5-593, but an isogenic condition is not needed (as explained above) for our experimental purpose.

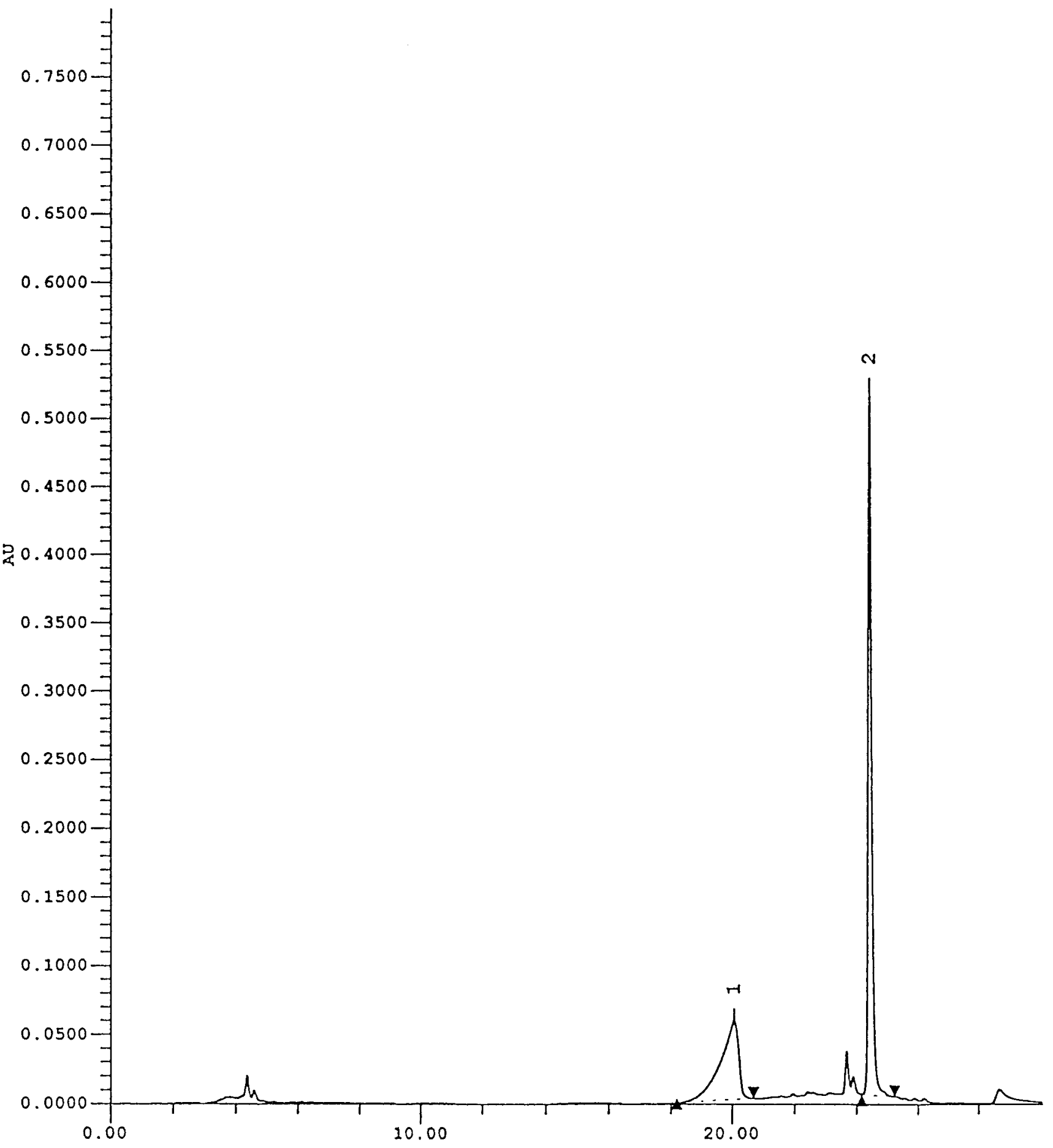

Fig. 1. HPLC profile of extract from the seedcoat of mineral-brown bean genotype; $1=$ unidentified mixture of minor flavonoids, $2=$ astragalin. 
The yellow and mineral brown genetic stocks were increased during summer 1996 in a nursery at the Saginaw Valley Bean and Sugarbeet Research Farm, Saginaw, Mich. The soil type on the farm is a Mistequay silty clay [fine, illitic (calcareous), frigid typic Haplaquolls]. After harvesting in the autumn, seeds were frozen at $-20^{\circ} \mathrm{C}$. Pale greenish-yellow seeds were planted in the greenhouse in January 1998 and were harvested in early April 1998. Plants were grown under solium lights with an 8 h daylength and watered as needed.

Instrumentation. A Waters (Waters Corp., Milford, Mass.) High-performance liquid chromatography (HPLC) system was used for the isolation and quantification of the compounds. This included a 600 multisolvent pump, 996 photo diode array detector, and 717 autosampler. Nuclear magnetic resonance (NMR) spectra were obtained on a VXR 500 MHZ (Oxford Instruments, Eynsham, Oxfordshire, United Kingdom) with Varian (Varian Associates, Palo Alto, Calif.) software at the Max T. Rogers NMR facility in the Dept. of Chemistry, Michigan State Univ.

Extraction AND ISOlation. Depending on the amount of beans available a number of $100 \mathrm{~g}$ (fresh weight) samples of beans were washed and then placed in distilled water to soak (Beninger et al., 1998b). There were six 100-g samples soaked for yellow brown, eighteen for mineral brown, and two for pale greenish yellow. After soaking, the seedcoats were separated from the cotyledons and then freeze-dried. The water exudate from the soaked beans was also freeze-dried and stored. Dried, ground, seedcoats from yellow brown (32.3 g), mineral brown (100.0 g), and pale greenish yellow ( $9.98 \mathrm{~g}$ ) beans were packed separately into glass columns and extracted sequentially with hexane, ethyl acetate (EtOAc), methanol $(\mathrm{MeOH})$, and $1 \mathrm{MeOH}: 1$ water. Extracts were dried under reduced pressure in a rotary evaporator, weighed, and transferred to vials.

Thin-LaYer Chromatography. To test for the presence of proanthocyanidins, the $\mathrm{MeOH}, \mathrm{MeOH}: \mathrm{H}_{2} \mathrm{O}$, and $\mathrm{H}_{2} \mathrm{O}$ extracts were chromatographed on Avicell (Analtech Inc., Newark, Del.) cellulose plates $(250 \mu \mathrm{m})$ in a solvent system of 4 butanol : 1 acetic acid : 5 water (Markham, 1982). Plates were then sprayed with 5\% vanillin in 4 ethanol : 1 concentrated hydrochloric acid.

Preparative hPlc. Yellow brown (100.8 mg), mineral brown, $(100.3 \mathrm{mg})$, and $100.0 \mathrm{mg}$ of the pale greenish yellow crude methanol extracts were dissolved in $1 \mathrm{ACN}: 3 \mathrm{H}_{2} \mathrm{O}$ and purified by preparative HPLC, using a reverse phase (RP) C18 CapCell Pak semipreparative column (AG120 A, $5 \mu \mathrm{m}, 10 \times 250 \mathrm{~mm}$ ) (Shiseido Co. Ltd., Chuo-ku, Tokyo, Japan) and a C18 CapCell Pak guard column (AG120 A, $5 \mu \mathrm{m}, 10 \times 20 \mathrm{~mm})$. The solvent system was $3 \mathrm{ACN}: 7 \mathrm{H}_{2} \mathrm{O}$ mobile phase at a flow rate of 1.0 $\mathrm{mL} \cdot \mathrm{min}^{-1}$ with detection scan set at 200 to $600 \mathrm{~nm}$. Astragalin was collected as a single peak with retention time of $20 \mathrm{~min}$, then purified further by reinjection under the same HPLC conditions.

Analytical HPlc. Three seeds from each of the genotypes were weighed, washed in distilled water, and soaked as above to separate the seedcoats from the cotyledons. Seedcoats were then transferred to mortars and a small amount of celite was added as an abrasive. The seedcoats were then extracted by grinding with a pestle, first with $100 \% \mathrm{MeOH}$, and then with $1 \mathrm{MeOH}: 1 \mathrm{H}_{2} \mathrm{O}$. This procedure was repeated with nine separate samples for each genotype to give nine replications. Extracts were then transferred to microcentrifuge vials and centrifuged at $20,000 g_{\mathrm{n}}$ for $10 \mathrm{~min}$. Supernatants were removed and evaporated to dryness in a rotary evaporator. Residues were redissolved in $1.0 \mathrm{~mL} 1 \mathrm{ACN}: 3 \mathrm{H}_{2} \mathrm{O}$ and the solutions filtered through a $0.20-\mu \mathrm{m}$ filter into HPLC injection vials. The standards kaempferol 3-O-glucoside and kaempferol 3-O-glucose-xylose identified previously in 'Prim' beans (Beninger et al., 1998a) were prepared as $1.0 \mathrm{mg} \cdot \mathrm{mL}^{-1}$ and then diluted serially to $0.5,0.25,0.125$, and $0.0625 \mathrm{mg} \cdot \mathrm{mL}^{-1}$. These standard solutions were injected immediately before the extracts. A calibration curve $\left(r^{2}=0.989\right)$ was calculated by Millenium 3.1 (Waters Corporation, Milford, Mass.) software and concentrations of astragalin were calculated and expressed as $\mathrm{mg} / 100 \mathrm{~g}$ of fresh bean weight. For quantification, an isocratic solvent system ( $1 \mathrm{ACN}: 3 \mathrm{H}_{2} \mathrm{O}$ ) was used at a flow rate of 1.0 $\mathrm{mL} \cdot \mathrm{min}^{-1}$ and detection at 200 to $600 \mathrm{~nm}$ (extraction wavelength was $347 \mathrm{~nm}$ ). For qualitative analysis a gradient method was used: $1 \mathrm{ACN}$ : $9 \mathrm{H}_{2} \mathrm{O}$ to $9 \mathrm{ACN}: 1 \mathrm{H}_{2} \mathrm{O}$ over 20 min with a total analysis time of $40 \mathrm{~min}$.

Statistical Analysis. Data were analyzed using the general linear models procedure with a Student-Newman-Keuls comparison of means (SAS Institute, Inc., Cary, N.C.).

\section{Results}

Analytical HPLC traces showed that flavonoid profiles of these three genotypes were virtually identical; only that of the mineral brown genotype is presented (Fig. 1). A flavonoid was isolated from the crude methanolic extracts of all three genotypes and was subjected to ${ }^{1} \mathrm{H}$ NMR and ${ }^{13} \mathrm{C}$ NMR analysis (Table 1). The downfield portion of the $1 \mathrm{D}^{1} \mathrm{H}$ NMR spectrum was characteristic of a kaempferol aglycon. The anomeric sugar protons were found as doublets at 5.44, 5.41, and 5.43 for yellow brown, mineral brown and pale greenish-yellow, respectively. The coupling constants for all anomeric protons were $>7.0 \mathrm{~Hz}$, indicating a $\beta$-linkage of the glucose residues to the aglycons. The $\mathrm{C} 3$ of the kaempferol isolated from each bean genotype was shifted upfield in the ${ }^{13} \mathrm{C}$ spectrum by $\approx 3.0 \mathrm{mg} \cdot \mathrm{mL}^{-1}$, indicating the glucose residues were attached at the $\mathrm{C} 3$ position of the aglycon. Therefore, the flavonol compound isolated from each of the three genotypes used in the study was identified as kaempferol 3-O- $\beta$ D-glucopyranoside (astragalin) (Fig. 2). Coinjection of the crude methanolic extract with $200 \mu \mathrm{g}$ astragalin standard increased the area and height of the peak at $24.0 \mathrm{~min}$ and confirmed the identification. In addition to astragalin, a second peak with a shorter retention time was found (Fig. 1). Attempts to isolate and purify compounds from this broad peak showed it was a mixture of trace flavonoid compounds, and we could not obtain enough material for NMR identification.

\section{Discussion}

Astragalin (kaempferol 3-O- $\beta$-D-glucopyranoside) was the main flavonoid found in all three genotypes, with small amounts of other flavonoid compounds. A flavonol diglycoside, kaempferol 3-O-glucose-xylose, which was a constituent of 'Prim' seedcoats, was not found in mineral brown, yellow brown or pale greenishyellow and may occur only in the pale-yellow manteca market class of dry bean due to the action of $j G b v$ (vs. $J G b v$ ) (Bassett, 1999; Beninger et al., 1998a). However, a related compound, which differs from the above diglycoside only in having an additional $\mathrm{OH}$ at the 3 ' position, viz., quercetin $3-O-\beta$-D-glucosexylose, has been found in red kidney seedcoats (Beninger et al., unpublished data). In addition, no anthocyanins were found in the three genotypes used in this study, which also had in common recessive $v$. Therefore, $V$ is probably necessary for production of anthocyanins.

Since the three genotypes did not differ qualitatively for the 
Table 1. Proton and carbon assignments obtained by NMR of astragalin from the seedcoats of three bean color genotypes.

\begin{tabular}{|c|c|c|c|c|}
\hline \multirow{3}{*}{$\begin{array}{l}\text { Proton and carbon } \\
\text { assignment }\end{array}$} & \multicolumn{4}{|c|}{ Spectral peak measurement $\left(\mathrm{mg} \cdot \mathrm{L}^{-1}\right)$} \\
\hline & \multicolumn{4}{|c|}{ Seedcoat color } \\
\hline & Yellow brown & Mineral brown & Pale greenish-yellow & Reference $^{\mathrm{z}}$ \\
\hline \multicolumn{5}{|l|}{${ }^{1} \mathrm{H} \mathrm{NMR}^{\mathrm{y}}$} \\
\hline $1 \mathrm{H}, \mathrm{s}, \mathrm{H}-5(\mathrm{OH})$ & 12.5 & 12.5 & 12.5 & 12.61 \\
\hline $1 \mathrm{H}, \mathrm{s}, \mathrm{H}-6$ & 6.17 & 6.15 & 6.16 & 6.21 \\
\hline $1 \mathrm{H}, \mathrm{s}, \mathrm{H}-8$ & 6.4 & 6.37 & 6.39 & 6.43 \\
\hline $2 \mathrm{H}, \mathrm{d}, J=9.06 \mathrm{~Hz}, \mathrm{H}-2^{\prime} 6^{\prime}$ & 8.02 & 8.02 & 8.03 & 8.04 \\
\hline $2 \mathrm{H}, \mathrm{d}, J=9.06 \mathrm{~Hz}, \mathrm{H}-3^{\prime} 5^{\prime}$ & 6.87 & 6.86 & 6.86 & 6.86 \\
\hline $1 \mathrm{H}, \mathrm{d}, J=7.54 \mathrm{~Hz}, \mathrm{H}-1 "$ & 5.44 & 5.41 & 5.43 & --- \\
\hline $1 \mathrm{H}, \mathrm{m}, \mathrm{H}-2^{\prime \prime}$ & 3.34 & 3.32 & 3.32 & --- \\
\hline $1 \mathrm{H}, \mathrm{m}, \mathrm{H}-3^{\prime \prime}$ & 3.14 & 3.12 & 3.12 & --- \\
\hline $1 \mathrm{H}, \mathrm{m}, \mathrm{H}-4 "$ & 3.2 & 3.22 & 3.22 & --- \\
\hline $1 \mathrm{H}, \mathrm{m}, \mathrm{H}-5^{\prime \prime}$ & 3.24 & 3.24 & 3.24 & --- \\
\hline $1 \mathrm{H}, \mathrm{d}, J=11.6, \mathrm{H}-6 \mathrm{~A}^{\prime \prime}$ & 3.55 & 3.55 & 3.55 & --- \\
\hline $1 \mathrm{H}, \mathrm{s}, \mathrm{H}-6 \mathrm{~B} "$ & 3.3 & 3.3 & 3.3 & --- \\
\hline \multicolumn{5}{|l|}{${ }^{13} \mathrm{C} \mathrm{NMR}^{\mathrm{x}}$} \\
\hline C-2 & 156.36 & 156.02 & 156.42 & 156.4 \\
\hline C-3 & 133.08 & 133.1 & 133.1 & 133.4 \\
\hline C-4 & 177.28 & 177.27 & 177.25 & 177.5 \\
\hline C-5 & 161.11 & 161.13 & 161.11 & 161.1 \\
\hline C-6 & 98.79 & 98.91 & 98.83 & 98.8 \\
\hline C-7 & 164.81 & 161.13 & 164.95 & 164.2 \\
\hline C-8 & 93.64 & 93.73 & 93.67 & 93.8 \\
\hline C-9 & 156.04 & 156.02 & 156.42 & 156.4 \\
\hline C-10 & 103.65 & 102.5 & 103.61 & 104 \\
\hline C-2', $6^{\prime}$ & 130.75 & 130.78 & 130.78 & 131 \\
\hline C- $3^{\prime}, 5^{\prime}$ & 115.02 & 115.06 & 115.02 & 115.1 \\
\hline C-1" & 100.87 & 100.94 & 100.94 & 100.7 \\
\hline C-2" & 74.22 & 74.17 & 74.15 & 74.2 \\
\hline C-3" & 77.39 & 77.42 & 77.42 & 77.3 \\
\hline C-4" & 69.88 & 69.86 & 69.86 & 69.8 \\
\hline C-5" & 76.36 & 76.4 & 76.39 & 76.4 \\
\hline C-6" & 60.76 & 60.81 & 60.8 & 60.8 \\
\hline
\end{tabular}

${ }^{\overline{21}} \mathrm{H}$ NMR = proton nuclear magnetic resonance, $\mathrm{s}=$ singlet, $\mathrm{d}=$ doublet, $\mathrm{m}=$ multiplet, $J=$ coupling constant in $\mathrm{Hz}$.

y Markham and Geiger (1993) for ${ }^{1} \mathrm{H}$ NMR and Agrawal and Bansai (1989) for ${ }^{13} \mathrm{C}$ NMR.

${ }^{\mathrm{x} 13} \mathrm{C} \mathrm{NMR}=$ carbon 13 nuclear magnetic resonance.

flavonoids present, we hypothesized that their quantities of astragalin might differ. Yellow brown had significantly less astragalin than mineral brown and pale greenish-yellow, viz., about half as much on average (Table 2). Since the $B$ locus is recessive $(b b)$ in yellow brown, $B$ may enhance production of astragalin. However, $G$ and $B$ are both recessive $(g g b b)$ in the pale greenish-yellow genotype, yet the concentration of astragalin was not significantly different from mineral brown $(G G B B)$. We explain these results, by suggesting that the main effects of genes controlling astragalin concentration are due to interactions of $J J$ vs. $j j$ with $G G$ and $B B$. Therefore, with $J J$ and $v v$ (common to all three genotypes studied herein) there is an increase in the production of astragalin with $G G B B$ and $g g b b$, as opposed to $G G b b$. In the case of 'Prim', which is recessive at $J(j j)$, an additional kaempferol compound (kaempferol 3-O-glucose-xylose) is produced (Beninger et al., 1998a). The function of the $B$ gene (with $J$ ) may be to maintain the concentration of astragalin at a "standard" equilibrium, whereas $G$ may shunt the astragalin into condensed tannins. Thus, with $G b$ the concentration of astragalin drops to a lower equilibrium level.

Astragalin may contribute to the yellow color of seedcoats as it does in the Manteca market class. However, its concentration was lowest in the yellow brown genotype, but the seedcoat of this genotype had the most intense yellow color. In the yellow brown genotype, astragalin occurred at only about a quarter the concentration of the total kaempferol glycosides found in the 'Prim' genotype (Beninger et al., 1998a). Thus, substitution of $j$ for $J$ in 'Prim' may reduce substantially the capacity of $G$ to convert the flavonols to proanthocyanidins, leading to an increased concen-

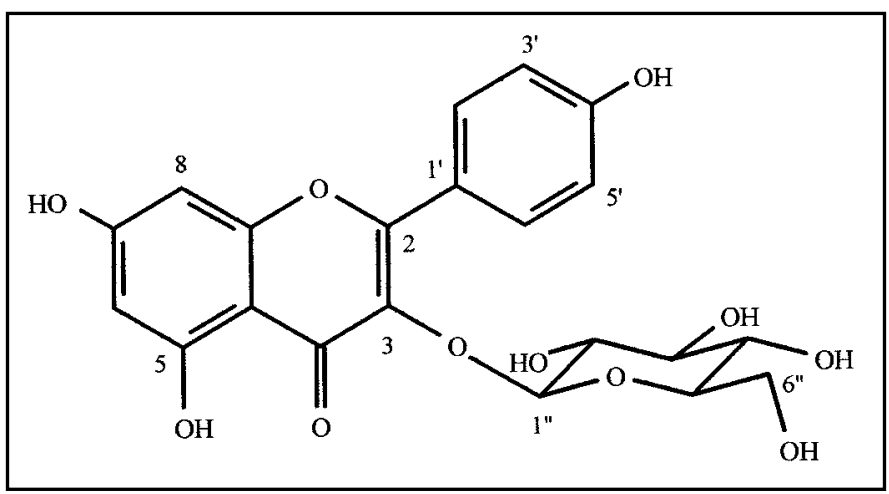

Fig. 2. Structure of astragalin (kaempferol 3-O- $\beta$-D-glucopyranoside). 
Table 2. Flavonoid concentrations in seedcoats of three color genotypes of dry bean.

\begin{tabular}{|c|c|c|c|}
\hline \multirow[b]{3}{*}{ Flavonoid } & \multicolumn{3}{|c|}{ Flavonoid concn (mg/100 g fresh wt) } \\
\hline & \multicolumn{3}{|c|}{ Color and genotype } \\
\hline & $\begin{array}{l}\text { Mineral brown } \\
P C D J G B v\end{array}$ & $\begin{array}{l}\text { Yellow brown } \\
P C D J G b v\end{array}$ & $\begin{array}{l}\text { Pale greenish-yellow } \\
\qquad P C D J g v\end{array}$ \\
\hline Kaempferol 3-O-glucoside & $23.23 \pm 2.87 \mathrm{a}^{\mathrm{z}}$ & $15.98 \pm 1.25 \mathrm{~b}$ & $24.58 \pm 1.72 \mathrm{a}$ \\
\hline Kaempferol 3-0-glucose-xylose & $--^{\mathrm{y}}$ & - & - \\
\hline Proanthocyanidins & $+^{\mathrm{x}}$ & + & + \\
\hline
\end{tabular}

${ }^{\bar{z}}$ Significant differences among means \pm se determined by a Student-Newman-Keuls test, $P \leq 0.05$.

yNot found.

xPresent.

tration of astragalin in 'Prim' compared with $J G B$ or $J g b$, and especially with $J G b v$. Color differences observed visually between the three genotypes studied are, therefore, probably not caused as much by the flavonoid monomers, as they are by subtle differences in the amounts and types of proanthocyanidins and their oxidation/polymerization derivatives present. Unaltered proanthocyanidins are colorless, but are known to be present in sorghum (Sorghum bicolor L. Moench) seedcoats that are different shades of brown that darken with development (Stafford, 1990). These shades that darken with development are probably due to secondary changes of the proanthocyanidins or the formation of complexes with other phenolics in the seedcoat (Stafford, 1990). Although quercetin ( $\left.3^{\prime}, 4^{\prime}-\mathrm{OH}\right)$ glycosides may be present in small amounts, it does not appear at this time that the main effect of $B$ results in a second ( $3^{\prime}$ ) hydroxylation of the kaempferol B-ring, as has been hypothesized by Leakey (1988).

Although the three genotypes studied in this work did not differ in the types of flavonoids present in methanol extracts, they differed slightly in the amount of astragalin present. Therefore, the color genes $G$ and $B$ do not influence color by their affect on the types of flavonoid monomers present. Genes $G$ and $B$ may act, at least in part, to increase the rate of tannin formation and the types of tannins that are formed, which in turn, affects the subtle variations in color that one observes in these seedcoats.

\section{Literature Cited}

Agrawal, P.K. and M.C. Bansai. 1989. Flavonoid glycosides, p. 283 355. In: P.K. Agrawal (ed.). Carbon-13 NMR of flavonoids. Elsevier, New York.

Bassett, M.J. 1998a. List of seed coat genetic tester stocks in the 5-593 genetic background. Annu. Rpt. Bean Improvement Coop. 41:125126.

Bassett, M.J. 1998b. The genotype for seed coat color and pattern of breeding line 5-593. 1998. Annu. Rpt. Bean Improvement Coop. 41:127-128.
Bassett, M.J. 1999. The seedcoat color genotype of 'Prim' and the Manteca and Coscorrón market classes of common bean. HortScience 34:336-337.

Beninger, C.W., G.L. Hosfield, and M.G. Nair. 1998a. Flavonol glycosides from the seedcoat of a new manteca-type dry bean (Phaseolus vulgaris L.) J. Agr. Food Chem. 46:2906-2910.

Beninger, C.W., G.L. Hosfield, and M.G. Nair. 1998b. Physical characteristics of dry beans in relation to seedcoat color genotype. HortScience 33:328-329.

Feenstra, W.J. 1960. Biochemical aspects of seedcoat color inheritance in Phaseolus vulgaris L. Med. Landbouwhogeschool Wageningen 60:1-53.

Heller, W. and G. Forkmann. 1988. Biosynthesis, p. 399-425. In: J.B. Harborne (ed.). The flavonoids. Chapman and Hall, New York.

Koes, R.E., F. Quattrocchio, and J.N.M. Mol. 1993. The flavonoid biosynthetic pathway: Function and evolution. BioEssays 16:123132.

Kooiman, H.W. 1931. Monograph on the genetics of Phaseolus (especially Ph. vulgaris and Ph. multiflorus). Bibliographia Genet. 8:295413.

Lamprecht, H. 1932. Beiträge zur Genetik von Phaseolus vulgaris. Zur Vererbung der Testafarbe. Hereditas 16:169-211.

Leakey, C.L.A. 1988. Genotypic and phenotypic markers in common bean, p. 245-327. In: P. Gepts (ed.). Genetic resources of Phaseolus beans. Kluwer Academic Publ., Boston.

Markham, K.M. 1982. Techniques of flavonoid identification. Academic Press, New York.

Markham, K.R. and H. Geiger. 1994. ${ }^{1} \mathrm{H}$ nuclear magnetic resonance spectroscopy of flavonoids and their glycosides in hexadeuterodimethylsulfoxide, p. 441-479. In: J.B. Harborne (ed.). The flavonoids: Advances in research since 1986. Chapman and Hall, New York.

Prakken, R. 1970. Inheritance of colours in Phaseolus vulgaris L. II. A critical review. Med. Landbouwhogeschool Wageningen 70:1-38.

Prakken, R. 1972. Inheritance of colours in Phaseolus vulgaris L. III. On genes for red seedcoat color and a general synthesis. Med. Landbouwhogeschool Wageningen 72:1-82.

Stafford, H.A. 1990. Flavonoid Metabolism. CRC Press, Boca Raton, Fla. 